\title{
DEVELOPMENT OF NEW OIL PALM CULTIVARS IN MALAYSIA
}

\section{KUSHAIRI, A* and MOHD DIN AMIRUDDIN*}

\begin{abstract}
At the beginning of the oil palm industry at the turn of the $20^{\text {th }}$ century, commercial plantations utilised the thick-shell thin-mesocarp dura planting materials. The breeds were unconsciously and informally selected from the 'best-looking' palms and fruits in the African palm groves or in subsequent decorative avenues elsewhere. Discovery of the single gene inheritance for shell thickness led to the use of the thinnershell thicker oil-bearing mesocarp dura $x$ pisifera (DxP) cultivated variety (cultivar). However, oil palm breeding populations had been derived from few ancestral palms, which hindered selection progress. The basic population of the maternal line in breeding programmes is almost exclusively the Deli dura. Improvements of tenera/pisifera paternal lines were mainly the AVROS, La Me and Yangambi populations. Malaysian oil palm breeders widely practiced the modified recurrent selection (MRS) in improvement programmes. Subsequent parental inbred lines developed in recurrent selections, crossed and progeny tested exploiting heterosis had boosted bunch and oil yields. The MRS allows incorporation of new genes into the parental lines; and coupled with the need to widen the genetic pool, wild Elaeis guineensis and E. oleifera germplasms were prospected in centres of origin and diversity in Africa and Latin America, respectively. Besides breeding for bunch and oil yields, secondary traits such as dwarfism, oil quality and phytonutrient contents are incorporated in developing PS series new varieties for niche purposes. A notable cultivar is PS1 characterised by short palm height. It takes more than 20 years from collection in the wild to the release of new cultivar. To speed up selection and release of cultivar, the preliminarily selected breeding materials are shared among local industry breeders for further breeding and improvements. In addition to quantitative genetics, further strides in cultivar development are supported by tissue culture, biotechnology and genomics. New varieties are registered based on the Test Guidelines for new, distinct, uniform and stable (DUS) of the International Union for the Protection of New Varieties of Plants (UPOV). Commercial production and sale of oil palm planting materials in Malaysia are regulated by law. Oil palm seed producers must be a registered company, financially sound and has a competent breeder. Seeds and seedlings for commercial sale must fulfill the requirements of Malaysian Standard MS157 (seeds) or MS2099 (clones) and subscribe to relevant certification schemes. Companies must obtain the license to produce, store, shipping and handling of the planting materials. Field performance of commercial oil palm planting materials are regularly evaluated in comparative trials.
\end{abstract}

Keywords: breeding, selection, planting materials, improvement, cultivars, oil palm.

Date received: 13 March 2019; Sent for revision: 14 March 2019; Accepted: 29 September 2019; Available online: 30 June 2020.

\section{INTRODUCTION}

The Russian geneticist and agronomist, N. I. Vavilov who conceived the origin of the crops

\footnotetext{
Malaysian Palm Oil Board,

6 Persiaran Institusi, Bandar Baru Bangi,

43000 Kajang, Selangor, Malaysia.

E-mail:mohddin@mpob.gov.my
}

and geographical distribution of cultivated plants inspired breeders to collect and conserve the genetic resources of crops. According to Vavilov, there are two centres of origin for oil palm (Rajanaidu et al., 2017) viz. West African Centre for Elaeis guineensis and North-South American Centre for E. oleifera. At the beginning of the oil palm industry at the turn of the $20^{\text {th }}$ century, commercial plantations utilised the 
thick-shell thin-mesocarp dura planting materials. The breeds were unconsciously and informally selected from the 'best-looking' palms and fruits in the African palm groves or in subsequent decorative avenues elsewhere. While acquiring open-pollinated seeds for avenue plantings, and the subsequent selection to supply seeds for more avenues, superior materials were unconsciously mass selected for several generations. The successful commercial planting of E. guineensis in 1917 in Tennamaran Estate, Kuala Selangor, Selangor has brought about substantial social and economic prosperity for Malaysia (Kushairi et al., 2018).

\section{Single Gene Inheritance}

Discovery of the single gene, namely shell gene (SH), inheritance for shell thickness (Beirnaert and Vanderweyen, 1941) led to the use of the thinner-shell thicker oil-bearing mesocarp dura $\mathrm{x}$ pisifera (DxP) cultivar. The single gene gave a 3:1 phenotypic ratio for shell (present:absent) and 1:2:1 genotypic ratio for fruit form (homozygous $\mathrm{SH}+\mathrm{SH}+$ dura:heterozygous $\mathrm{SH}+\mathrm{SH}$ - tenera: homozygous $\mathrm{SH}-$ SH- pisifera). Since 1960, commercial plantings were based on the tenera hybrids. An increase of more than $30 \%$ oil yield was realised with the switch from the dura to the tenera planting material. With the advent of the DxP planting materials, breeding programmes were diverted to select the dura and pisifera to generate the tenera seedlings (Figure 1).

However, oil palm breeding populations have been derived from few ancestral palms, which hindered selection progress. The history of oil palm breeding populations has been traced by a number of authors (Jagoe, 1952; Hardon and Thomas, 1968; Arasu and Rajanaidu, 1975; 1976; Rosenquist, 1986; Lubis, 1990).

\section{Deli Dura Breeding Population}

The oil palm industry in the East Asia owes its beginning to four dura seedlings introduced at the Bogor botanical garden, Indonesia in 1848 (Hartley, 1988). Seeds from Bogor were planted for esthetical purposes along avenues in Sumatra, notably in Deli, in 1870s (Kushairi, 1992). Materials from Sumatra were imported to Malaya (now known as Malaysia) in several occasions, but those planted along avenues in Rantau Panjang, Selangor in the 1910s mooted the oil palm industry in Malaysia. It should be realised that while acquiring open-pollinated seeds for avenue plantings and the subsequent selection to supply seeds for more avenues, superior materials were unconsciously mass selected for several generations. Formal breeding and selections were carried out since the 1920s in Indonesia at Marihat Baris Estate, and in Malaya at Elmina Estate and Serdang Experimental Station (Hardon and Thomas, 1968). After intense breeding and selections, these palms had become uniform in performance, yielding big bunches, good fruit characteristics with high mesocarp content. This population became known as Deli dura population. The Deli dura sub-populations in Malaysia (Serdang Avenue, Elmina, Dumpy E206, Ulu Remis and Johore Labis) are considered Breeding Populations of Restricted Origin (BPRO).

\section{Tenera/Pisifera Breeding Populations}

Some common tenera/ pisifera paternal lines were Yangambi, AVROS, Serdang 27B, NIFOR, La Me and derived pisifera but improvements mainly involved the AVROS, La Me and Yangambi populations. The pisiferas were generated from either tenera $\mathrm{x}$ tenera $(\mathrm{TxT})$, tenera $\mathrm{x}$ pisifera $(\mathrm{Tx} \mathrm{P})$ or pisifera $\mathrm{x}$ pisifera $(\mathrm{P} \times \mathrm{P})$ crosses. The oil palm cultivated variety (cultivar) is

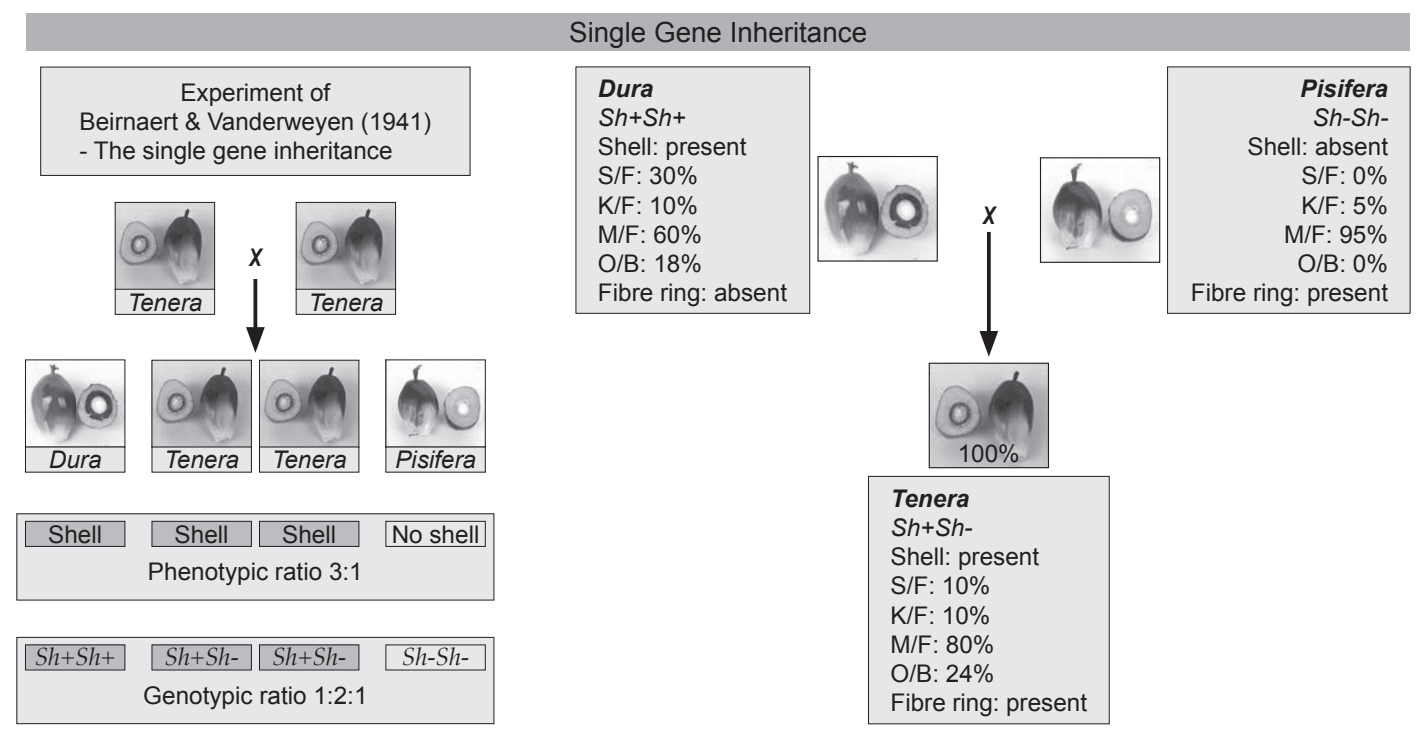

Figure 1. Discovery of single gene inheritance for shell and development of dura $x$ pisifera (DxP) cultivar. 
the common DxP planting material, which normally comprises the Deli dura x AVROS pisifera cross.

\section{Improvement Programmes}

A modified recurrent selection (MRS) plan is practised by a majority of Malaysian oil palm breeders (Figure 2). In the MRS method, selected duras are crossed in various combinations using North Carolina Model I (NCM I) breeding design and the progenies planted in replicated trials. The NCM I mating design involves the crossing of a male (pisifera) with a set of 3-5 females (duras). Several sets of crosses are made to make up a trial. After a minimum of four years of yield recording, and 3-5 bunches per palm had been analysed (determination of oil content), the palms were then selected for seed production and to generate the next cycle of dura mother palms. Yield over the first four years is highly correlated with yield from the $11^{\text {th }}$ to $16^{\text {th }}$ years (Blaak, 1965). Higher heritabilities are obtained from means of several years and a plateau value is approached for yield and bunch number after 3-4 years (Corley and Tinker, 2016). As pisifera palms are normally female sterile, there is no direct way to evaluate its worth. Thus, the yield potential and fruit qualities of the pisiferas are determined indirectly by progeny testing the selected pisiferas with elite duras. Based on the tenera performance in the same DxP progeny test experiment, pisiferas that show good general combining ability (GCA) are selected for seed production. Introduction of new genes can be made into the breeding programme to increase the genetic variability (Hardon, 1970). The FFB and oil yields have been shown to increase (Lee and Toh, 1992).

Whilst, the pisiferas that give the best average performance in progeny trials are chosen, the duras are selected in dura x dura (DxD) genetic blocks based on their own merits. Dura mother palms, on average, produce 6-8 bunches per year with 1000-2000 seeds per bunch, while the pollen of the pisifera palms can be used to pollinate many female inflorescences. Each male inflorescence of a mature palm produces about $30 \mathrm{~g}$ pollen, but harvesting of $100 \mathrm{~g}$ pollen is not uncommon. Thus, only a small number of individual pisifera palms (especially involving AVROS and some Yangambi) are the fathers of practically every oil palm that is grown commercially. The MRS involves inter-crossing among the selected parents and carrying progenies forward to the next cycle. Subsequent parental inbred lines developed in recurrent selections, crossed and progeny tested exploiting heterosis had boosted bunch and oil yields. The MRS allows incorporation of new genes into the parental lines.

\section{Germplasm Collections}

The oil palm has been footed on a narrow genetic base, the Deli dura being derived from four Bogor palms whereas the pisiferas from limited sources (AVROS, La Me and Yangambi). Coupled with the need to widen the genetic pool, wild Elaeis guineensis

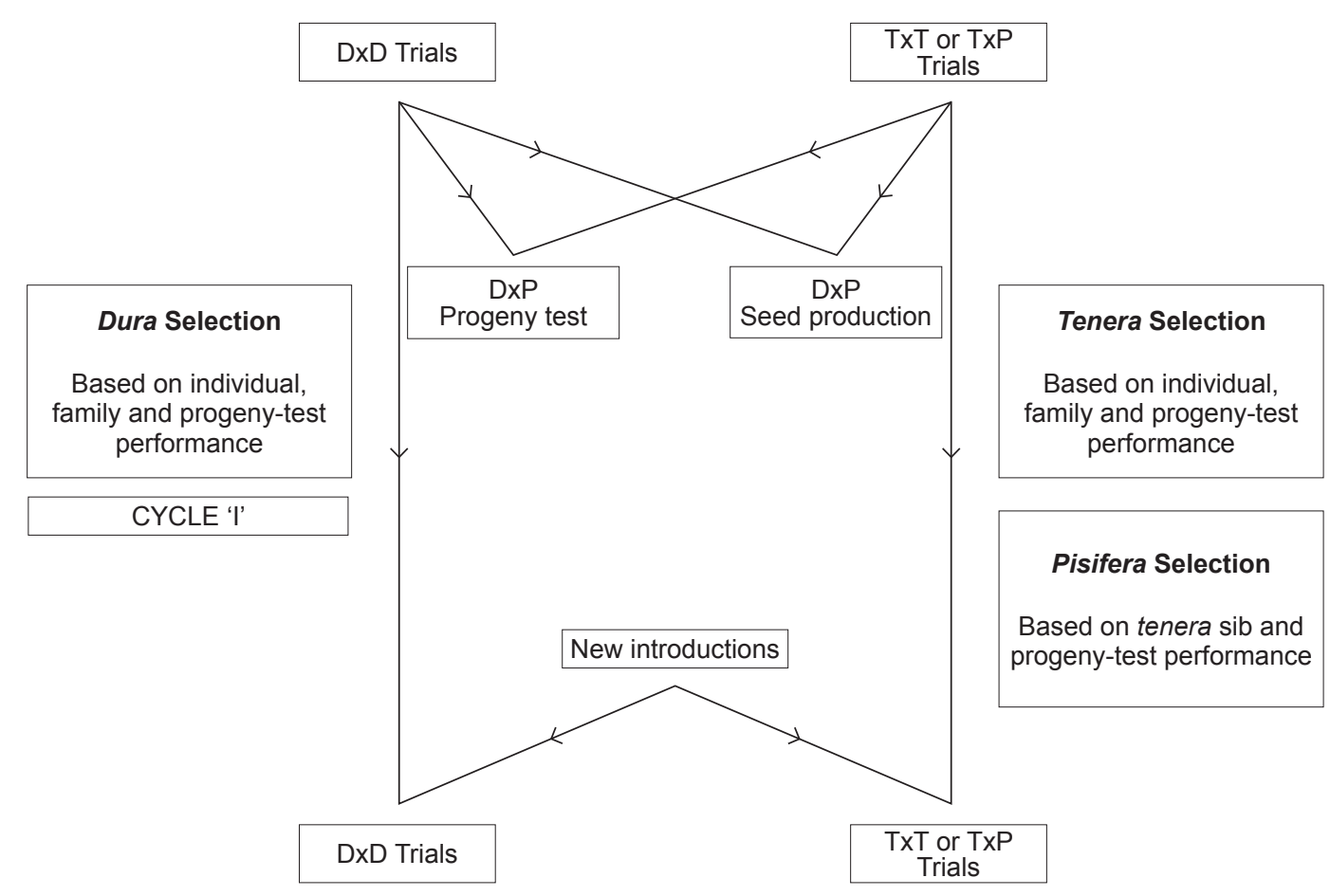

Source: Rajanaidu et.al. (2000).

Figure 2. Modified recurrent selection scheme. 
and E. oleifera germplasms were prospected in centres of origin and diversity in Africa and Latin America, respectively. The need for new materials of sufficient genetic variability to improve and safeguard the crop has been widely acknowledged for a long time (Hartley, 1988). The establishment of oil palm genetic resources as in any other crops, depends on the successful execution of major tasks - exploration, evaluation, improvement, utilisation and conservation.

\section{Development of Secondary Traits}

Besides breeding for bunch and oil yields, secondary traits such as dwarfism, oil quality and phytonutrient contents are incorporated in developing PS series (Rajanaidu et al., 2008; Noh et al., 2015) new varieties for niche purposes. Since 1992, 14 distinct genotypes have been distributed successfully to members of the industry.

The genotypes are the high yielding dwarf (PS1), high iodine value (PS2), large kernel (PS3), high carotene E. oleifera (PS4), thin-shelled teneras (PS5), large fruit duras (PS6), high bunch index (PS7), high vitamin E (PS8), exotic palm - Bactris gasipaes (PS9), long stalk (PS10), high carotene E. guineensis (PS11), high oleic acid (PS12), low lipase (PS13) and high protein kernel (PS14). These technologies were announced to the industry during MPOB annual Transfer of Technology (TOT) Seminars. Members of the industry are interested and adopted these technologies to use in their oil palm breeding and improvement programmes.

\section{Selection}

A notable cultivar is PS1 characterised by short palm height. It takes more than 20 years from collection in the wild to the release of new cultivar. Current DxP planting materials grow at 40-75 $\mathrm{cm} \mathrm{yr}^{-1}$ and difficult to harvest after 20 years. One of the main priorities in oil palm is breeding for shorter palms. In 1982, extensive evaluation for yield, bunch traits, fatty acid composition, physiological parameters and vegetative characters were carried out. A number of genotypes were available to breed for dwarf palms. These elite palms were distributed to the members of the industry for progeny testing, introgression into the current breeding materials and to initiate new breeding lines for future seed production.

To speed up selection and release of cultivar, the preliminarily selected breeding materials were shared among local industry breeders for further breeding and improvements. After undergoing extensive progeny-testing, MPOB was also able to breed shorter planting materials (PS1.1) based on MPOB-Nigerian population 12.

Population 12 from MPOB-Nigerian germplasm was unique, being high yielding, short and compact.
Some of the crosses produced high oil yield and 30\% shorter than DxP control (Rajanaidu et al., 2013). Thus, it is easier to harvest and more amenable for mechanisation as well as reducing the production cost.

In addition to quantitative genetics, further strides in cultivar development are supported by tissue culture, biotechnology and genomics.

\section{Clonal Seeds}

Using tissue culture technology, clonal seeds can be produced. Clonal seeds are produced using parents with good specific combining ability (SCA). Some Malaysian breeding programmes are using self of the parents. Semi-clonal seeds are produced using either parent (dura clone $\mathrm{x}$ pisifera; dura $\mathrm{x}$ pisifera clone) as clones whereas bi-clonal seeds are produced using both parents (dura clone $\mathrm{x}$ pisifera clone) as clones.

\section{Planting Materials}

Hence, breeding programmes for production of oil palm planting materials involve production of DxP seeds (exploitation of general combining ability), clonal DxP seeds (exploitation of specific combining ability) and clones (individual palms). The duration from nursery to field take nine months for DxP and clones. Fast track approach for production of palms with special traits such as high bunch index, high vitamin E, high carotene, long stalk and low height increment has been pursued via cloning.

\section{Genomics-guided Breeding}

The revolution in life sciences signalled by genomics dramatically change the scale and scope of application in plant improvement. Application of genomics-based technologies is well suited for oil palm and this has led to huge investments in the area of plant genomics to help improve the speed and efficiency for producing new and improved planting materials. However, application of genomic-based technologies in plant breeding is not possible without systematic development of breeding programmes. In fact, systematic development of classical breeding programmes and precise phenotypic data collection forms the backbone of improvement using genomicbased approaches (Mohd Din et al., 2011).

With the sequence of the palm genome now completed by MPOB and others, it is worth turning our attention to the beginning of a new and exciting era of genomics-guided breeding. The use of the genome sequence in oil palm breeding has a high potential for success. Classical breeding, by family and recurrent selection, has a long selection cycle requiring many years and many hectares to advance elite palms. Marker-assisted selection, and even 
genomic selection, will greatly speed-up this process, as traits can be predicted long before they are scored.

\section{Oil Palm Genome Programme}

MPOB is the first organisation to sequence and release the genome sequence of both species of oil palm, namely Elaeis guinnensis and Elaeis oleifera, through a high impact and highly cited publication (Singh et al., 2013a). The identification of the SHELL gene linked to the formation of SHELL in the fruit was also identified (Singh et al., 2013b). Since then, the gene for fruit colour (Singh et al., 2014) and the epigenetic change that results in the abnormal mantled fruits had also been identified (Meilina et al., 2015). Diagnostic services to screen planting materials for these three traits had been developed. MPOB now strives to identify other traits that are also important to oil palm, such as yield, low height increment, disease resistance and fatty acid composition.

\section{Convention on Biological Diversity (CBD)}

The Convention on Biological Diversity (CBD) is a United Nations treaty formally adopted in Rio de Janeiro, Brazil in 1992. CBD recognises biological resources as sovereign rights of nations. Malaysia, being a party to CBD deposits equal portion of oil palm germplasm collection in the host country.

\section{Plant Breeders Right (PBR) - Test Guidelines for New, Distinct, Uniform and Stable (DUS)}

New varieties are registered based on the Test Guidelines for New, Distinct, Uniform and Stable of the International Union for the Protection of New Varieties of Plants (UPOV). The aim of the guidelines is to protect new oil palm varieties developed. Varieties are a form of intellectual rights and the developer/breeder should be given exclusivity to them to deter others from exploiting them. This gives them a chance to earn back their investment ploughed into research and to incentivise them to do more for the greater benefit of mankind. The Oil Palm DUS Test Guidelines were developed under the purview of the Department of Agriculture, Malaysia and officially published in February 2010 (Department of Agriculture Malaysia, 2010). Harmonised DUS TG of oil palm involves Malaysia (chair), Indonesia and Thailand under the East Asia Plant Variety Protection Forum (EAPVPF), Japan.

\section{Malaysian Standard}

The Department of Standards Malaysia (Standards Malaysia) is the national standardisation and accreditation body. Malaysian Standards are developed through consensus by committees which comprise of balanced representation of producers, users, consumers and others with relevant interests. To the greatest extent possible, Malaysian Standards are aligned to or are adoption of international standards. Approval of a standard as a Malaysian Standard is governed by the Standards of Malaysia Act 1996 (Act 549).

Seeds and seedlings for commercial sale must fulfill the requirements of Malaysian Standard MS157 - Oil Palm Seeds for Commercial Planting: Specification or MS2099 - Oil Palm Clones for Commercial Planting. Specification for Ortet Selection. Companies must obtain the license to produce, store, ship and handle the planting materials. Contamination by illegitimate pollen is a major hindrance to quality in seed production. Hence, extreme care must be exercised to prevent dura contamination, which is a crucial aspect for oil palm seed producers. The occurrence of thickshelled dura in DxP crosses is due to illegitimate pollen. Thus, strict quality control measures should be followed during crossing to ensure the validity of the controlled pollination.

MS2099 was developed to ensure production authenticity for desired productivity and sustenance of the oil palm industry, where only high quality ramets, derived from high quality ortets, are produced. The MS includes requirements for ortet selection, guidelines on production practices, packaging and legal matters.

Malaysian Standards are reviewed periodically. The use of Malaysian Standards is voluntary except in so far as they are made mandatory by regulatory authorities by means of regulations, local by-laws or any other similar ways.

\section{Legal Requirements}

Producers of oil palm planting materials must obtain license to produce, store and move the planting materials. Producers must be a registered company, financially sound and have a competent breeder. Seeds, clones and seedlings for commercial sale must fulfill the requirements of Malaysian Standard MS157 (seeds) or MS2099 (clones). The seeds and clones shall in all aspects comply with the requirements of the legislations currently in force in Malaysia.

\section{License for Oil Palm Seeds and Clones for Commercial Planting}

This is a Related Legislation where Malaysian Standards are voluntary according to the Department of Standards Malaysia (Standards Malaysia). However, MS157 (seeds) and MS2099 (clones) are mandatory standards imposed by MPOB on producers regulated under the MPOB (Licensing) Regulations 2005. The industry is 
generally very well regulated and any revisions to improve the standards will immediately be imposed on producers.

\section{Comparative Trials for Evaluation of Malaysian DxP}

Field performance of commercial oil palm planting materials is regularly evaluated in comparative trials. MPOB, in cooperation with the industry, has carried out routine evaluation on the performance of Malaysian DxP to monitor the quality of planting materials produced locally (Kushairi, 1992; Kushairi et al., 1994; 1997;1999; 2000; 2001; Isa et al., 2005; Mohd Din et al., 2014). To date, four rounds of evaluation have been completed.

\section{CONCLUSION}

Development of new oil palm cultivars owes a great deal to the work and dedication initiated by early breeders. Science, laws and regulations facilitate development and release of new cultivar and healthy growth of the industry.

\section{ACKNOWLEDGEMENT}

The authors wish to thank all staff from different divisions at MPOB for their contribution to this article.

\section{REFERENCES}

Arasu, N T and Rajanaidu, N (1975). Conservation and utilization of genetic resources in the oil palm (Elaeis guineensis Jacq.). South East Asia Genetic Resources (William, J T ed.). p. 182-186.

Arasu, N T and Rajanaidu, N (1976). Oil palm genetic resources. International Developments in Oil Palm (Earp, D A and Newall, W eds.). Incorporated Society of Planters, Kuala Lumpur. p. 16-25.

Beirnaert, A and Vanderweyen, R (1941). Contribution a l'etude genetique et biometrique des varieties d'Elaeis guineensis Jacq. Publication INEAC. Serie Scienfifique No. 27.

Blaak, G (1965). Breeding and inheritance in the oil palm (Elaeis guineensis Jacq.) Part III. Yield selection and inheritance. J. West Afr. Inst. Oil Palm Res., 4: 262283.

Corley, R H V and Tinker, P B (2016). The Oil Palm Fifth Edition. Wiley Blackwell. 159 pp.
Department of Agriculture Malaysia (2010). Guidelines for the Conduct of Tests for Distinctness, Uniformity and Stability (DUS) in Oil Palm (Elaeis guineensis Jacq.). Department of Agriculture Malaysia. 77 pp.

Hardon, J J (1970). Inbreeding in populations of the oil palm (Elaeis guineensis Jacq.) and its effects on selection. Oleagineux, 25: 449-456.

Hardon, J J and Thomas R L (1968). Breeding and selection of oil palm in Malaya. Oleagineux, 23(2): 85-90.

Hartley, C W S (1988). The Oil Palm. Longmans, London. 958 pp.

Isa, Z A; Chin, CW; Sharma, M; Chia, C C; Kushairi, A; Rajanaidu, N and Mohd Din, A (2005). Performance of Malaysian DxP $-3^{\text {rd }}$ round evaluation. Proc. of the 2005 Nat. Sem. Breed. and Clonal Tech. Seri Kembangan, Selangor. p. 95-137.

Jagoe, R B (1952). 'Deli' oil palms and early introduction of Elaeis guineensis to Malaya. Malay. Agric. J. (35): 4-11.

Kushairi, A (1992). Prestasi Baka Kelapa Sawit Dura x Pisifera di Malaysia. M.Sc. Thesis. Universiti Kebangsaan Malaysia. 149 pp.

Kushairi, A; Rajanaidu, N; Jalani, B S and Zakri, A H (1994). Variation in dura x pisifera planting materials. 1: Bunch yield. Elaeis, 6(1): 14-24.

Kushairi, A; Jalani, B S; Ariffin Darus and Rajanaidu, N (1997). Seed production and export of Malaysian oil palm planting materials. The Planter, 73(853): 185200.

Kushairi, A; Rajanaidu, N; Jalani, B S and Mohd Isa, Z A (1999). PORIM Series 1 - PORIM elite oil palm planting materials. PORIM Information Series No. 15: 2 pp.

Kushairi, A; Rafii, M Y; Rajanaidu, N and Jalani, B S (2000). Yield potential of various sources of planting materials in Malaysia. Incorporated Society of Planters Sabah North-East Branch Seminar Oil Palm Yield Potential, Trends and Forecasting. 23-24 March 2000. Renaissance Sandakan Hotel, Sandakan, Sabah.

Kushairi, A; Rafii, M Y; Rajanaidu, N and Isa, Z A (2001). Assessment of performance of Malaysian oil palm planting materials. Proc. of the 2001 PIPOC International Palm Oil Congress-Agriculture Conference. $\mathrm{MPOB}$, Bangi.

Kushairi, A; Soh Kheang Loh; Azman, I; Elina Hishamuddin; Meilina Ong-Abdullah; Zanal Bidin Mohd Noor Izuddin; Razmah G; Shamala Sundram 
and Ghulam Kadir Ahmad Parveez (2018). Oil palm economic performance in Malaysia and R\&D progress in 2017. J. Oil Palm Res. Vol. 30(2): 163-195.

Lee, C H and Toh, P Y (1992). Yield performance of Golden Hope OPRS DxP planting material. Yield Potential in the Oil Palm (Rao, V; Henson, I E and Rajanaidu, N eds.). PORIM, Bangi. p. 24-29.

Lubis, A U (1990). History and origin of oil palm breeding materials used in Marihat Research Centre. Proc. of the Workshop Progress of Oil Palm Breeding Populations. PORIM, Bangi. p. 103-119.

Meilina Ong-Abdullah; Jared M Ordway; Nan Jiang; Siew-Eng Ooi; Sau-Yee Kok; Norashikin Sarpan; Nuraziyan Azimi; Ahmad Tarmizi Hashim; Zamzuri Ishak; Samsul Kamal Rosli; Fadila Ahmad Malike; Nor Azwani Abu Bakar; Marhalil Marjuni; Norziha Abdullah; Zulkifli Yaakub; Mohd Din Amiruddin; Rajanaidu Nookiah; Rajinder Singh; Eng-Ti Leslie Low; Kuang-Lim Chan; Norazah Azizi; Steven W Smith; Blaire Bacher; Muhammad A Budiman; Andrew Van Brunt; Corey Wischmeyer; Melissa Beil; Michael Hogan; Nathan Lakey; ChinChing Lim; Xaviar Arulandoo; Choo-Kien Wong; Chin-Nee Choo; Wei-Chee Wong; Yen-Yen Kwan; Sharifah Shahrul Rabiah Syed Alwee; Ravigadevi Sambanthamurthi and Robert A Martienssen (2015). Loss of Karma transposon methylation underlies the mantled somaclonal variant of oil palm. Nature, 525(7570): 533-537.

Mohd Din, A; Rajinder, S; Meilina, O A; Ravigadevi, S and Rajanaidu, N (2011). Oil palm breeding: The anchor for genome-based technology. Proc. of the PIPOC 2011 International Palm Oil Congress Agriculture Conference. MPOB, Bangi. p. 535-545.

Mohd Din, A; Rajanaidu N; Tarmizi A H; Kushairi, A; Noh, A; Marhalil, M; Zulkifli, Y; Norziha, A and Meilina, O A (2014). Performance and yield potential of oil palm planting materials. The Planter, 1065: 881904.

Noh, A; Rajanaidu, N; Kushairi, A; Mohd Din, A and Wan Nooraida, W M (2015). PS 14: Oil palm breeding population selected for high protein kernel. $M P O B$ Information Series No. 566. 4 pp.

Rajanaidu, N; Kushairi, A; Rafii, M; Mohd Din, A; Maizura, I and Jalani, B S (2000). Chapter 6: Oil palm breeding and genetic resources. Advances in Oil Palm Research. Vol. 1. MPOB, Bangi. p. 171-237.

Rajanaidu, N; Kushairi, A; Mohd Din, A; Maizura, I and Noh, A (2008). A review on utilization and performance of MPOB PS Series genetic materials. Proc. of the $3^{\text {rd }}$ Sem. PS1 \& PS2 and Elite Germplasm. MPOB, Bangi. p. 3-42.
Rajanaidu, N; Kushairi A; Marhalil, M; Mohd Din, A; Fadila, A; Noh, A; Meilina, O A; Isa, Z A; Chan, K W and Ravigadevi, S (2013). Breeding of oil palm for strategic requirement of the industry. Proc. of the PIPOC 2013 International Palm Oil Congress - Green Opportunities from the Golden Crop. MPOB, Bangi. 6 pp.

Rajanaidu, N; Kushairi, A and Mohd Din, A (2017). Monograph Oil Palm Genetic Resources. MPOB, Bangi. 289 pp.

Singh, R; Meilina Ong-Abdullah; Eng-Ti Leslie Low; Mohamad Arif Abdul Manaf; Rozana Rosli; Rajanaidu Nookiah; Leslie Cheng-Li Ooi; SiewEng Ooi; Kuang-Lim Chan; Mohd Amin Halim; Norazah Azizi; Jayanthi Nagappan; Blaire Bacher; Nathan Lakey; Steven W Smith; Dong He; Michael Hogan; Muhammad A Budiman; Ernest K Lee; Rob Desalle; David Kudrna; Jose Louis Goicoechea; Rod Wing; Richard K Wilson; Robert S Fulton; Jared M Ordway; Robert A Martienssen and Ravigadevi Sambanthamurthi (2013a). Oil palm genome sequence reveals divergence of interfertile species in old and new worlds. Nature, 500(7462): 335-339.

Singh, R; Eng-Ti Leslie Low; Leslie Cheng-Li Ooi; Meilina Ong-Abdullah; Ting Ngoot Chin; Jayanthi Nagappan; Rajanaidu Nookiah; Mohd Din Amiruddin; Rozana Rosli; Mohamad Arif Abdul Manaf; Kuang-Lim Chan; Mohd Amin Halim; Norazah Azizi; Nathan Lakey; Steven W Smith; Muhammad A Budiman; Michael Hogan; Blaire Bacher; Andrew Van Brunt; Chunyan Wang; Jared M Ordway; Ravigadevi Sambanthamurthi and Robert A Martienssen (2013b). The oil palm SHELL gene controls oil yield and encodes a homologue of SEEDSTICK. Nature, 500(7462): 340-344.

Singh, R; Eng-Ti Leslie Low; Leslie Cheng-Li Ooi; Meilina Ong-Abdullah; Rajanaidu Nookiah; Ngoot-Chin Ting; Marhalil Marjuni; Pek-Lan Chan; Maizura Ithnin; Mohd Arif Abdul Manaf; Jayanthi Nagappan; Kuang-Lim Chan; Rozana Rosli; Mohd Amin Halim; Norazah Azizi; Muhammad A Budiman; Nathan Lakey; Blaire Bacher; Andrew Van Brunt; Chunyan Wang; Michael Hogan; Dong He; Jill D Macdonald; Steven W Smith; Jared M Ordway; Robert A Martienssen and Ravigadevi Sambanthamurthi (2014). The oil palm VIRESCENS gene controls fruit colour and encodes a R2R3-MYB. Nat. Commun., 5: 4106.

Rosenquist, E A (1986). The genetic base of oil palm breeding population. Proc. International Worksop on Oil Palm Germplasm and Utilization. PORIM, Bangi. p. 27-56. 